\title{
Keanekaragaman dan Potensi Lobster (Malacostraca: Palinuridae) di Pantai Pameungpeuk, Garut Selatan, Jawa Barat
}

\author{
Rianta Pratiwi ${ }^{1}$ \\ ${ }^{1}$ Bidang Biodiversitas dan Potensi Sumberdaya Hayati Laut, Pusat Penelitian Oseanografi-LIPI \\ Jl. Pasir Putih 1. Ancol Timur, Jakarta 14430 (Tel.: 62.21.6471.38.50; Fax: 62.21.6471.19.48; \\ E-mail: pratiwiafriadi@gmail.com
}

\begin{abstract}
Coral shrimp (Panulirus spp.) or known as lobster is a potential fishery commodity and economic value. The demand for domestic and export market continues to increase both as local consumption and export. Indonesia is the largest lobster fishery producer in almost all Indonesian waters, from the west coast of Sumatra to the east coast Jayapura, one of which is Pameungpeuk beach, South Garut, West Java. As a result of increasing demand, fishermen try to catch as many lobsters and the impact of lobster prices also in creases and whereas fishermen continuously take it from nature. This study was conducted to determine the diversity and potential of lobster species especially living in high wavy waters along the southern coast of Garut (Pamengpeuk), West Java. The results of observation are only three types of crayfish, namely: a. Panulirus homarus (green lobster sand); b. Panulirus longipes (lobster flower/ red lobster) and Panulirus versicolor (green lobster/bamboo); is most commonly found in the area of south Garut, Pameungpeuk beach with high and strong waves. The percentage of female $P$ longipes species $(42.88 \%)$ was higher compared to male $P$. homarus (40\%) and ovigerous female of $\mathrm{P}$. versicolor $(37.14 \%)$. While the sexual ratio between $P$. homarus (1:2.0:2.0); $P$. longipes $(1: 1.2: 1.0)$ and $P$. versicolor: 1:1.2:1.2 which statistically showed significantly different $\mathrm{p}<0.05$.
\end{abstract}

Key Words : Lobster, Panulirus spp.,_dominance, Pameungpeuk, South Garut.

\begin{abstract}
Abstrak
Udang karang (Panulirus spp.) atau lebih dikenal dengan sebutan lobster merupakan komoditas perikanan yang potensial dan bernilai ekonomis penting. Permintaan untuk pasar domestik dan eksport terus meningkat baik sebagai konsumsi lokal maupun eksport. Indonesia merupakan penghasil perikanan lobster terbesar hampir di seluruh perairan Indonesia, dari pantai barat Sumatera hingga pantai timur Jayapura, salah satunya adalah pantai Pameungpeuk, Selatan Garut, Jawa Barat. Akibat permintaan yang terus meningkat, maka nelayan berusaha untuk menangkap lobster sebanyak banyaknya dan sebagai dampaknya harga lobster meningkat, sedangkan nelayan terus menerus mengambilnya dari alam. Penelitian ini dilakukan untuk mengetahui keanekaragaman dan potensi dari jenis-jenis lobster terutama yang hidup di perairan bergelombang tinggi sepanjang pantai Selatan Garut (Pamengpeuk), Jawa Barat. Dari hasil pengamatan hanya tiga jenis udang karang, yakni: a. Panulirus homarus (lobster hijau pasir), b. Panulirus longipes (lobster bunga/lobster merah) dan c. Panulirus versicolor (lobster hijau/bambu) yang paling banyak ditemukan di daerah Selatan Garut, pantai Pameungpeuk dengan gelombang tinggi dan kuat. Persentase jenis betina $P$ longipes (42,88\%) lebih tinggi dibandingkan jenis jantan $P$. homarus $(40 \%)$ dan betina bertelur $P$. versicolor $(37,14 \%)$. Sedangkan rasio kelamin antara $P$. homarus jantan, betina dan betina bertelur adalah: 1: $2,0: 2,0$. $P$. longipes $1: 1,2: 1,0$ dan $P$. versicolor $1: 1,2: 1,2$ yang secara statistik berbeda nyata $p<0,05$.
\end{abstract}

Kata kunci : Lobster, Panulirus spp.,_dominansi, Pameungpeuk, Selatan Garut.

\section{Pendahuluan}

Pameungpeuk adalah sebuah kecamatan di Kabupaten Garut, Provinsi Jawa Barat, Indonesia. Kawasan ini dengan bentangan pantainya sepanjang $82 \mathrm{~km}$, sangat potensial untuk dikembangkan menjadi obyek wisata yang lebih elegan. Keindahan pantainya disebabkan adanya area berkarang sepanjang $32 \mathrm{~km}$ dan deburan ombak besar Samudera Hindia (Sugandi \& Supriatin, 2008).

Pantai selatan Garut, selain keindahan pantainya terdapat juga berbagai potensi yang dapat dikembangkan sebagai wisata edukasi antara lain terdapatnya: lobster atau udang karang di pantai Selatan Garut yang cukup berlimpah. Di Selatan Garut, hampir semua wilayah perairan pantainya memiliki karang- karang yang merupakan habitat berkembang biaknya lobster (Sugandi \& Suprihatin, 2008).

Lobster di Pantai Selatan Garut perlu diamati untuk memberikan informasi pengetahuan dalam memahami keberadaannya oleh karenanya, pengamatan (penelitian) perlu dilakukan guna melihat dan mengetahui potensi dari jenis-jenis crustacea yang ada di sepanjang pantai Pamengpeuk. Penelitian ini dilakukan untuk mengetahui jenis-jenis lobster yang hidup di perairan bergelombang tinggi.

Di Indonesia, perairan potensial penghasil lobster, selain Pantai Selatan Garut, tersebar mulai dari pantai Barat dan pantai Timur Sumatera, pantai Utara dan Selatan Jawa (Gunung Kidul, Cilacap dan Pacitan), Teluk Bone, Selatan Makasar, Laut Maluku hingga Arafura (Mahdiana \& Laurensia, 2011). Di Jogyakarta lobster merupakan komoditi yang penting. 
Berdasarkan data statistik perikanan di provinsi tersebut meskipun kontribusinya hanya $3 \%$, namun nilai produksinya mencapai 2,8 milyard rupiah. Produksi lobster di Indonesia dipasok hampir dari semua provinsi, dimana Jawa memberikan kontribusi sebesar $10,4 \%$ dari total produksi lobster di Indonesia pada periode 19972007 (Fauzi et al., 2013). Udang karang (Panulirus spp.) ditemukan hanya enam (6) jenis. Kondisi habitat lobster berbeda-beda tergantung dari jenisnya (Pratiwi, 2013).

Lobster secara taksonomi termasuk dalam kelompok Arthopoda, Kelas Malacostraca, Bangsa Decapoda, Suku Palinuridae dan Marga Panulirus yang sudah dikenal di seluruh dunia, sementara itu secara ekobiologi lobster merupakan hewan nocturnal yang hidup di substrat berbatu, berpasir atau berlumpur dan biasanya bersembunyi di celah-celah atau di bawah karang-karang batu dan atau di daerah terumbu karang baik di daerah tropis maupun sub-tropis. Sebagai hewan yang bersifat omnivora lobster akan memakan mangsa hidup seperti ikan, moluska, krustasea kecil, cacing, dan beberapa tumbuhan.

Lobster merupakan salah satu komoditas ekonomis penting baik sebagai konsumsi lokal maupun eksport (Febrianti, 2000; Fauzi et al., 2013). Tingkat permintaan lobster terus meningkat sangat tinggi untuk pasar domestik maupun eksport. Pemenuhan permintaan pasar yang tinggi, mendorong peningkatan upaya penangkapan lobster dari alam (Setyono, 2006; Mahdiana \& Laurensia, 2011). Pengamatan aspek biologi lobster di perairan Pantai Selatan Garut sangat penting untuk memahami "life history" dan pelestarian sumberdaya lobster serta menunjung pariwisata edukasi.

\section{Metode}

Sampling dilakukan di beberapa pantai yang terdapat di daerah Pameungpeuk, Selatan Garut, Jawa Barat (Pantai Bubujung, Pantai Karang Paranje, Pantai Santolo Indah, Pantai Karang Papak, Pantai Taman Manalusu, Pantai Cicalobak, Pantai Karang Wangi, Pantai Ranca Buaya 2 dan Pantai Ranca Buaya1). (Gambar 1) dengan ttitik koordinat masing-masing tercantum pada Tabel 1. Penelitian dilakukan pada bulan Mei 2016 di sepanjang pantai Pameungpeuk, Selatan Garut. Pengambilan sampel dilakukan oleh nelayan dengan cara menggunakan alat tangkap "Bubu Lipat (Badong)" dan "Krendet" (Gambar 2) yang telah diberi umpan, diletakkan pada sore hari dan diambil pada pagi hari. Cara penyelaman sangat berbahaya, sehingga alat hanya ditebarkan dari kapal atau dari bukit. Selain itu dilakukan juga pengumpulan data ke tempat pengumpul lobster untuk mengetahui data biologi seperti: panjang karapas $(\mathrm{mm})$, berat lobster (gr), jenis kelamin dan kondisi perkembangan hidupnya berdasarkan Moosa \& Aswandy (1984).

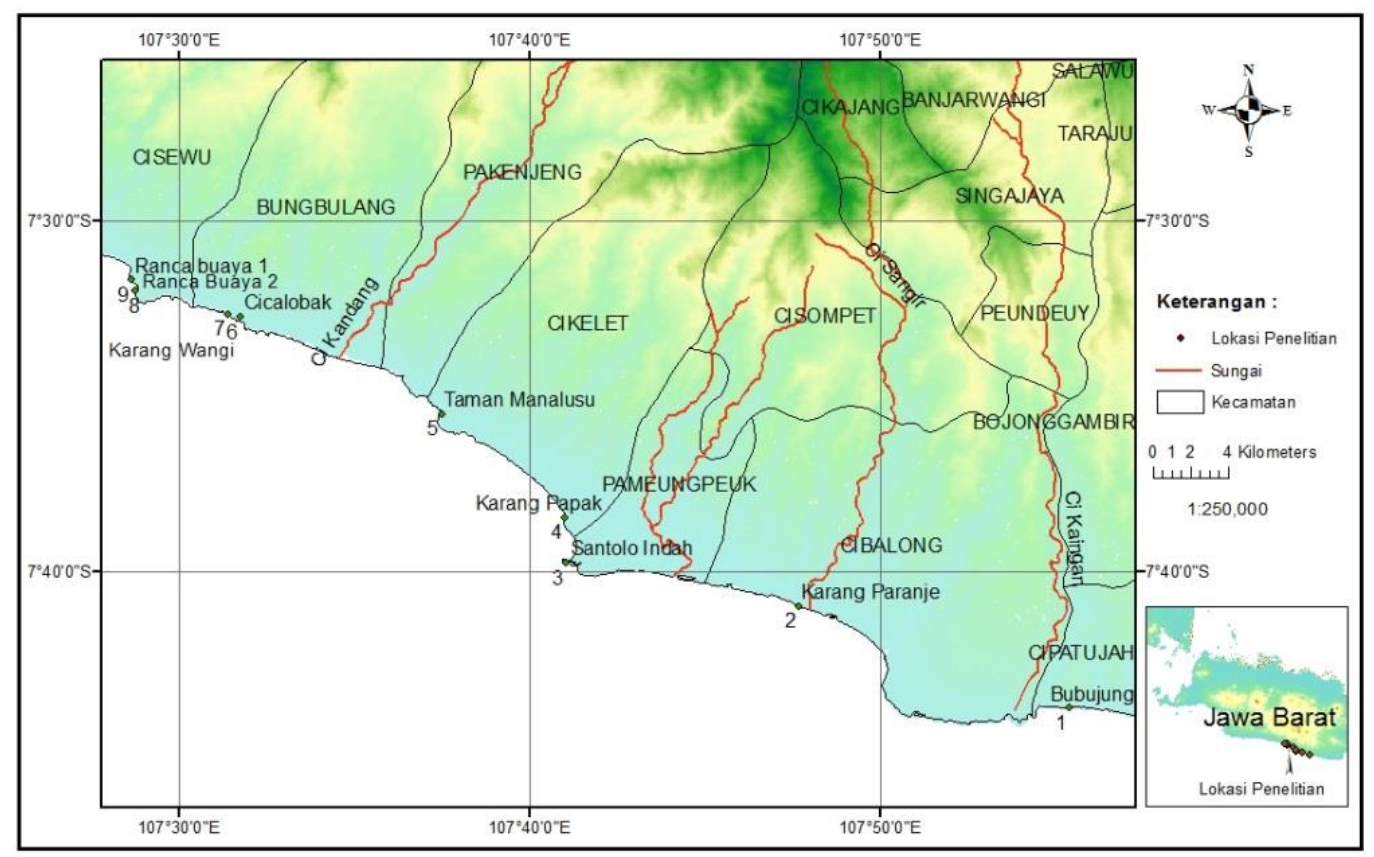

Gambar 1. Lokasi Penelitian Lobster di Daerah Pemengpeuk, Selatan Garut 
Tabel 1. Koordinat Lokasi Sampling Crustacea di daerah Pamengpeuk dan Sekitarnya

\begin{tabular}{|c|c|c|c|}
\hline Stasiun & Lokasi & Lintang Selatan & Bujur Timur \\
\hline 1 & Pantai Bubujung & $-7073^{\prime} 19.40 "$ & 107092'33.90" \\
\hline 2 & $\begin{array}{l}\text { Pantai Karang } \\
\text { Paranje }\end{array}$ & -7068'33.30” & 107079'48.10" \\
\hline 3 & Pantai Santolo Indah & $-7066 ’ 27.00 "$ & 107068 '44.40" \\
\hline 4 & Pantai Karang Papak & $-7064 ' 11.60 "$ & 107068 '36.30" \\
\hline 5. & $\begin{array}{l}\text { Pantai Taman } \\
\text { Manalusu }\end{array}$ & $-7059^{\prime} 18.00 "$ & 107062'49.30" \\
\hline 6. & Pantai Cicalobak & $-7054^{\prime} 54.60 "$ & 107052'95.30" \\
\hline 7. & Pantai Karang Wangi & $-7054^{\prime} 39.50 "$ & 107052 '36.60" \\
\hline 8. & $\begin{array}{l}\text { Pantai Ranca Buaya } \\
2\end{array}$ & $-7053^{\prime} 29.90 "$ & 107047'94.80" \\
\hline 9. & $\begin{array}{l}\text { Pantai Ranca Buaya } \\
1\end{array}$ & -7052'78.20”' & $107047 ' 76.20 "$ \\
\hline
\end{tabular}

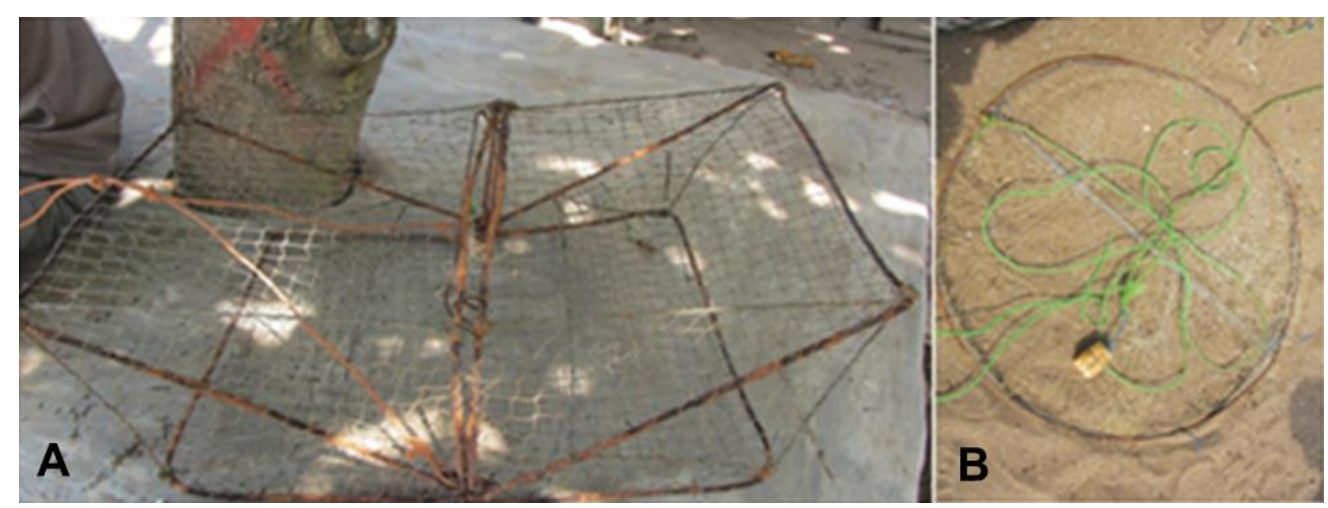

Gambar 2. Alat Tangkap Lobster. A. Bubu Lipat (Badong) dan B. Krendet.

Data panjang dan berat diukur dengan cara mengukur panjang karapas menggunakan calliper digital dengan ketelitian $(0,1 \mathrm{~mm})$ dan menimbang berat tubuh individu lobster menggunakan timbangan analitik dengan nilai ketelitian 0,01 gram. Jumlah individu jantan, betina dan betina bertelur setiap jenis diambil secara random dari sampel nelayan dan dihitung. Nisbah kelamin jantan dan betina (sex ratio) masing-masing jenis dianalisis dengan uji Chi Squer $\left(\mathrm{X}^{2}\right)$ dengan tingkat kepercayaan 95\% (Steel, \& Torrie, 1993). Hubungan panjang karapas dengan berat individu menggunakan persamaan Bal \& Rao (1984) dan Effendi (2002), yaitu:

$$
W=a L^{b}
$$

Dimana $\mathrm{W}$ adalah berat lobster (gr), L adalah panjang karapas $(\mathrm{mm})$, a adalah konstanta dan $b$ adalah nilai eksponensial antara 2-5. Berdasarkan persamaan tersebut dapat diketahui pola pertumbuhan panjang dan bobot lobster. Selanjutnya untuk mengetahui sifat pertumbuhan lobster dilakukan uji- $t$ terhadap koefisien pertumbuhan (nilai b) yang diperoleh dari persamaan regresi antara panjang karapas dengan berat tubuh lobster.

\section{Hasil dan Pembahasan}

\section{Pengamatan kondisi lobster di alam}

Di Indonesia udang karang ditemukan hanya enam (6) jenis, menyebar di perairan Indonesia Barat hingga Indonesia Timur dan mempunyai habitat yang berbeda. Ke enam jenis tersebut adalah: Udang Kendal, Udang Rejuna, Udang Barong, Lobster Hijau atau Lobster Bambu (Panulirus versicolor); Udang Jaka atau Udang Batu (Panulirus penicillatus); Udang Bunga atau Raja Udang (Panulirus longipes); Udang Ketangan, Udang Cemara atau Lobster Mutiara (Panulirus ornatus); Udang Jarak (Panulirus polyphagus); dan Udang Pantung, Udang Bireng atau Lobster Hijau Pasir (Panulirus homarus) (Moosa, 1984; Moosa \& Aswandy, 1984; Romimohtarto \& Juwana, 1999; Setyono, 2006, Pratiwi, 2013).

Hasil dari Pantai Pameungpeuk, hanya tiga jenis yang dominan yaitu: $P$. homarus, $P$. longipes dan $P$. versicolor (Gambar 3). Lobster tersebut sangat dominan karena merupakan jenis udang karang yang terdapat di perairan karang dan terumbu karang beriklim tropis, subur dan 
mempunyai suhu rata-rata $28^{\circ} \mathrm{C}$ (Fauzi et al., 2013). Lobster tersebut biasanya ditemukan di daerah terumbu karang, bersembunyi di dalam lubang, di bawah atau di balik batu-batu karang dengan gelombang air laut yang tinggi dan kuat.
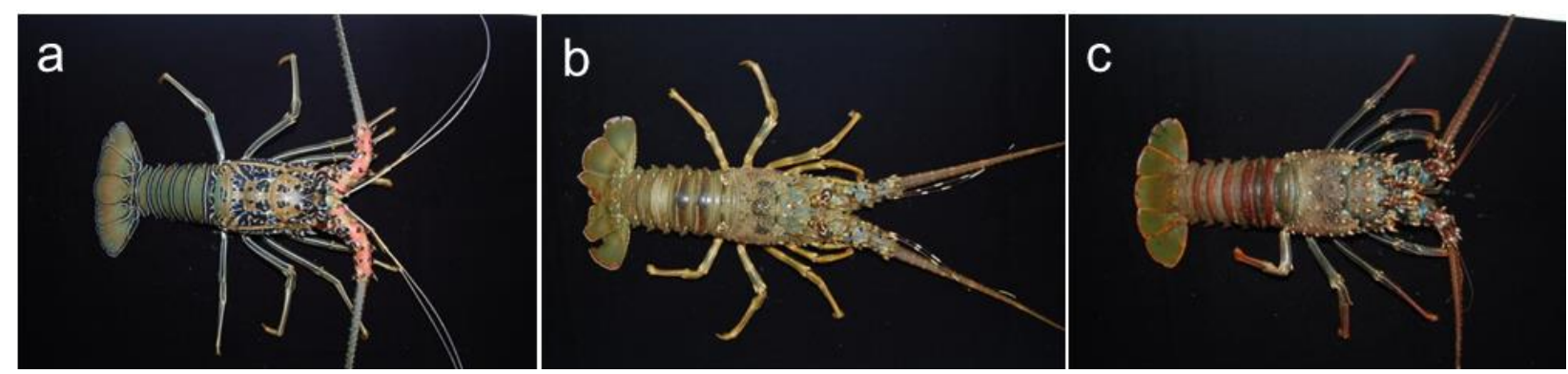

Gambar 3. Jenis-jenis Lobster yang Ditemukan di Pantai Ranca Buaya, Pamengpeuk, Selatan Garut. a. Panulirus versicolor (lobster hijau/bambu); b. Panulirus homarus (Lobster Hijau Pasir); c. Panulirus longipes (Lobster Bunga).

\section{Habitat, morfologi dan sebaran}

Tiga jenis yang ditemukan di Ranca Buaya, Cicalobak, Karang Papak dan Karang Wangi, mereka hidup bersembunyi di lubang-lubang, di bawah dan di balik karang dengan perairan yang bergelombang tinggi dan kuat. $P$. versicolor ditemukan di Karang Papak di daerah perairan dangkal dan bersembunyi dalam karang batu dan $P$. homarus di Karang Wangi ditemukan berkelompok di bawah batu karang, sedangkan di Ranca Buaya ditemukan lobster dewasa $P$. homarus, $P$. longipes dan $P$. versicolor, di substrat pasir bawah karang batu (Gambar 3).

Secara morfologi $P$. homarus memiliki permukaan bagian atas ruas abdomen dengan alur melintang berbentuk lurus dan bagian tepi bergerigi. Permukaan bagian atas ruas abdomen tidak berambut kecuali pada alur melintang, tepi belakang ebdomen dan lekuk yang berada di bagian sisi (Gambar 3b). Memiliki warna dasar kehijauan atau kecoklatan dengan bintik-bintik terang tersebar diseluruh permukaan segmen abdomen. Kaki dengan bercak-bercak putih (Gambar 3b). Jenis ini hidup di perairan terumbu karang hingga kedalaman beberapa meter, dan terlindung di antara batu-batu karang serta jarang hidup berkelompok. Udang jenis ini sangat sulit ditangkap dengan menggunakan alat tangkap, seringkali ditangkap dengan cara menyelam. Tersebar mulai dari pulau Sumatera, Jawa, bali, Nusa Tenggara, Timor Leste, Sulawesi, Halmahera dan Ambon (Pratiwi, 2013).

$P$. longipes memiliki ciri-ciri bagian permukaan ruas abdomen tidak berambut, hanya terdapat bulu-bulu keras tersebar dimana-mana dan tidak rapat (Gambar 3c). Warna dasar kecoklatan dengan warna kebiruan pada ruas pertama antenna. Abdomen dengan bintik-bintik warna putih, kaki jalan juga berbintik-bintik putih dengan warna pucat memanjang di setiap ruas kaki. Tempat hidup sedikit terlindung (tidak langsung dipengaruhi oleh ombak) dan menyukai perairan yang oseanik. Tinggal di dalam lubang batu karang dan akan naik ke permukaan untuk mencari makan pada malam hari. Di pantai Selatan Jawa, lobster ini seringkali ditangkap dengan menggunakan jaring yang dipasang di tubir, sedangkan di tempat yang lebih dalam ditangkap dengan jalan menyelam Romimohtarto \& Juwana (1999). Sebaran dari jenis lobster adalah di pulau Jawa, Bali, Kalimanta, Sulawesi dan Ambon.

$P$. versicolor sangat berwarna warni dan indah, Antenna bagian dasar dan bagian sisi karapas berwarna merah jambu. Warna dasar adalah hijau terang dengan garis putih melintang yang diapit dengan warna hitam. Sedangkan warna dasar udang muda adalah kebiruan atau keunguan. Permukaan bagian atas ruas abdomen tidak mempunyai alur melintang dan rambut, kecuali pada bagian tepi belakang dan lekuk yang terdapat pada bagian sebelah sisi. Bagian belakang terdapat garis melintang yang bergerak dari tepi sebelah kiri ke tepi sebelah kanan (Gambar 3a). Jenis ini hidup di perairan terumbu karang hingga kedalaman 40 meter, dan terlindung di antara batu-batu karang serta jarang hidup berkelompok. Udang jenis ini sangat sulit ditangkap dengan menggunakan alat tangkap, seringkali ditangkap dengan cara menyelam. Adapun sebaran dari lobster tersebut meliputi pulau Sumatera, Jawa, Nusa Tenggara Timur, Timor Leste, Sulawesi, Halmahera, Ambon dan Kepulauan Key (Pratiwi, 2013).

Lobster-lobster tersebut aktif di malam hari (nocturnal). Jenis $P$. versicolor hidup di perairan terumbu karang pada kedalaman 1-4 meter dan terlindung di antara batu-batu karang serta jarang hidup berkelompok. Udang jenis ini sangat sulit ditangkap dengan menggunakan alat tangkap, seringkali ditangkap dengan cara menyelam. $P$. longipes tempat hidup sedikit terlindung (tidak langsung dipengaruhi oleh ombak) dan menyukai perairan yang oseanik. Tinggal di dalam lubang 
batu karang dan akan naik ke permukaan untuk mencari makan pada malam hari. Di pantai Selatan Jawa (Pameungpeuk) lobster ini seringkali ditangkap dengan menggunakan jaring yang dipasang di tubir. Sedangkan $P$. homarus dijumpai pada perairan dangkal sampai kedalaman beberapa meter dan tinggal di dalam lubang-lubang batu karang. Hidup berkelompok dalam jumlah banyak, dan bisa ditangkap dengan perangkap yang diberi umpan atau ditangkap saat menyelam. Udang muda sangat toleransi dengan kekeruhan, sedangkan udang dewasa lebih menyukai perairan yang cerah.

Rasio Kelamin (Nilai nisbah)
Hasil penelitian didapatkan total lobster sebanyak 69 individu terdiri dari tiga jenis lobster yaitu: $P$. homarus (20 individu: 4 jantan, 8 betina dan 8 betina bertelur), $P$. longipes (14 individu: 5 jantan, 6 betina dan 3 betina bertelur) dan $P$. versicolor (35 individu: 9 jantan, 13 betina dan 13 betina bertelur) (Gambar 4). Pengamatan lobster di sepanjang pantai Pameungpeuk dan jumlah lobster serta persentase jenis $P$. homarus, $P$. longipes dan $P$. versicolor (jantan, betina dan betina bertelur) hasil analisanya disajikan pada Tabel 2. dan Gambar 4 \& 5, sedangkan $P$. homarus, $P$. longipes dan $P$. versicolor untuk ukuran panjang karapas, panjang total dan berat dapat dilihat pada Tabel 3a,b, c dan Gambar 6a,b dan C.

Tabel 2. Hasil Pengamatan Lobster di Pantai Pameungpeuk, Selatan Garut, Jawa Barat

\begin{tabular}{|c|c|c|c|c|c|c|c|c|c|}
\hline \multirow[b]{2}{*}{ Lokasi } & \multirow[b]{2}{*}{ Hasil } & \multirow[b]{2}{*}{ Nama Jenis } & \multirow[b]{2}{*}{ Habitat } & \multicolumn{3}{|c|}{ Jmh individu } & \multirow[b]{2}{*}{$\hat{\sigma}$} & \multirow[b]{2}{*}{ o } & \multirow[b]{2}{*}{$\begin{array}{c}\stackrel{+}{+} \\
\text { bertelur }\end{array}$} \\
\hline & & & & $\begin{array}{c}P . \\
\text { homarus }\end{array}$ & $\begin{array}{c}P . \\
\text { longipes }\end{array}$ & $\begin{array}{c}P . \\
\text { versicolor }\end{array}$ & & & \\
\hline $\begin{array}{l}\text { Pantai } \\
\text { Bubujung }\end{array}$ & - & - & - & - & - & - & - & - & - \\
\hline $\begin{array}{l}\text { P. Karang } \\
\text { Paranje }\end{array}$ & - & - & - & - & - & - & - & - & - \\
\hline $\begin{array}{l}\text { P. Santolo } \\
\text { Indah }\end{array}$ & - & - & - & - & - & - & - & - & - \\
\hline \multirow{2}{*}{$\begin{array}{l}\text { P. Karang } \\
\text { Papak }\end{array}$} & \multirow[b]{2}{*}{$\sqrt{ }$} & $\begin{array}{l}\text { Panulirus homarus } \\
\text { (lobster hijau pasir) }\end{array}$ & $\begin{array}{l}\text { dalam lubang- } \\
\text { lubang karang }\end{array}$ & 4 & - & - & - & 2 & 2 \\
\hline & & $\begin{array}{l}\text { Panulirus longipes } \\
\text { (lobster bunga) }\end{array}$ & $\begin{array}{l}\text { berlindung di } \\
\text { bawah karang } \\
\text { batu }\end{array}$ & - & 2 & - & 2 & - & - \\
\hline $\begin{array}{l}\text { P. Taman } \\
\text { Manalusu }\end{array}$ & - & - & - & - & - & - & - & - & - \\
\hline \multirow{2}{*}{ Cicalobak } & \multirow{2}{*}{$\sqrt{ }$} & $\begin{array}{l}\text { Panulirus versicolor } \\
\text { (lobster hijau/bambu) }\end{array}$ & terumbu karang & - & - & 6 & 2 & 2 & 2 \\
\hline & & $\begin{array}{l}\text { Panulirus homarus } \\
\text { (lobster hijau pasir) }\end{array}$ & $\begin{array}{l}\text { dalam lubang- } \\
\text { lubang karang }\end{array}$ & 1 & - & - & 1 & - & - \\
\hline \multirow{2}{*}{$\begin{array}{l}\text { P. Karang } \\
\text { Wangi }\end{array}$} & \multirow[b]{2}{*}{$\sqrt{ }$} & $\begin{array}{l}\text { Panulirus versicolor } \\
\text { (lobster hijau/bambu }\end{array}$ & terumbu karang & - & - & 3 & 1 & 1 & 1 \\
\hline & & $\begin{array}{l}\text { Panulirus longipes } \\
\text { (lobster bunga) }\end{array}$ & $\begin{array}{l}\text { berlindung di } \\
\text { bawah karang } \\
\text { batu }\end{array}$ & - & 3 & - & 1 & 2 & - \\
\hline \multirow{3}{*}{$\begin{array}{l}\text { P. Ranca } \\
\text { Buaya } 2\end{array}$} & \multirow{3}{*}{$\sqrt{ }$} & $\begin{array}{l}\text { Panulirus versicolor } \\
\text { (lobster hijau/bambu) }\end{array}$ & terumbu karang & - & - & 15 & 3 & 6 & 6 \\
\hline & & $\begin{array}{l}\text { Panulirus homarus } \\
\text { (lobster hijau pasir) }\end{array}$ & $\begin{array}{l}\text { dalam lubang- } \\
\text { lubang karang }\end{array}$ & 7 & - & - & 2 & 3 & 2 \\
\hline & & $\begin{array}{l}\text { Panulirus longipes } \\
\text { (lobster bunga) }\end{array}$ & $\begin{array}{l}\text { berlindung di } \\
\text { bawah karang } \\
\text { batu }\end{array}$ & - & 5 & - & - & 2 & 3 \\
\hline \multirow{4}{*}{$\begin{array}{l}\text { P. Ranca } \\
\text { Buaya } 1\end{array}$} & \multirow{4}{*}{$\sqrt{ }$} & Panulirus versicolor & terumbu karang & - & - & 11 & 3 & 4 & 4 \\
\hline & & $\begin{array}{l}\text { Panulirus homarus } \\
\text { (lobster hijau pasir) }\end{array}$ & $\begin{array}{l}\text { dalam lubang- } \\
\text { lubang karang }\end{array}$ & 8 & - & - & 3 & 3 & 2 \\
\hline & & $\begin{array}{l}\text { Panulirus longipes } \\
\text { (lobster bunga) }\end{array}$ & $\begin{array}{l}\text { berlindung di } \\
\text { bawah karang } \\
\text { batu }\end{array}$ & - & 4 & - & 2 & 2 & - \\
\hline & & & Total (69) & 20 & 14 & 29 & 20 & 27 & 22 \\
\hline
\end{tabular}


Hasil analisis gabungan antara ketiga jenis lobster untuk jantan, betina dan betina bertelur, terlihat bahwa jenis betina $P$. longipes (14; $42,86 \%)$ lebih tinggi persentasenya dibandingkan jenis betina $P$. homarus $(20 ; 40,00 \%)$ dan betina bertelur $P$. versicolor $(35 ; 37,14 \%)$. Jenis jantan $P$. longipes pun $(14 ; 35,70 \%)$ lebih tinggi dari pada $P$. homarus $(20 ; 20,00 \%)$ dan betina bertelur $P$. versicolor $(35 ; 25,71 \%)$. Akan tetapi jenis betina bertelur $P$. longipes $(14 ; 21,43 \%)$ lebih rendah dari jenis betina bertelur $P$. homarus (20; $40,00 \%$ ) dan betina bertelur P. versicolor (35; $37,14 \%$ ). Hal ini disebabkan rasio kelamin, betina, betina bertelur dan jantan pada populasi di alam umumnya seimbang atau hampir seimbang.
Ratio lobster betina $120 \%$ : lobster betina bertelur $98,57 \%$ dan lobster jantan $81,41 \%$ dari jumlah keseluruhan tangkapan. Beda ratio antara ketiga jenis tersebut tidak begitu jauh, dapat dianggap seimbang. Pengamatan tersebut hampir sama dengan penelitian yang dilakukan oleh Mahdiana \& Laurensia (2011) di perairan Cilacap, dimana ration lobster jantan $52,38 \%$ dan lobster betina $47,62 \%$, dinyatakan ratio seimbang, karena kondisi tersebut berkaitan dengan kelestarian populasi. Populasi dinyatakan dengan perbandingan kelamin yang seimbang (jantan dan betina perbandingan rationya seimbang), sehingga kelestarian populasi di alam bisa terjaga.

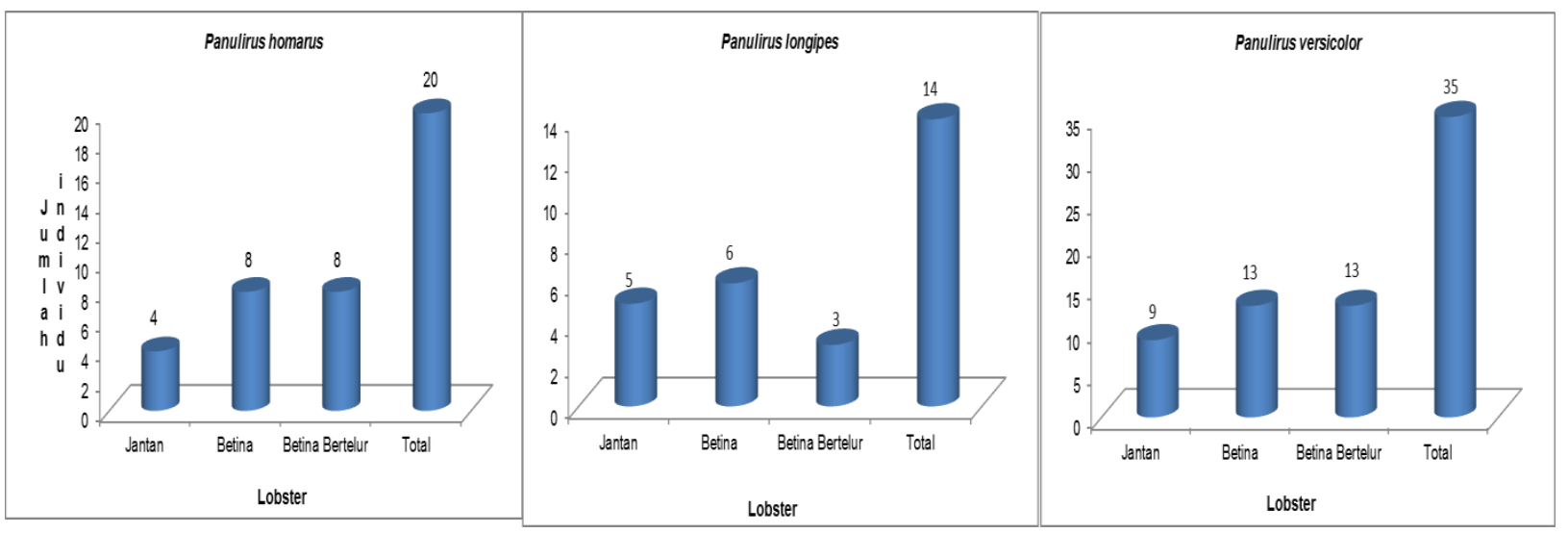

Gambar 4. Jumlah Individu Lobster Panulirus homarus, P. Iongipes dan P. versicolor (Jantan, Betina dan Betina Bertelur)

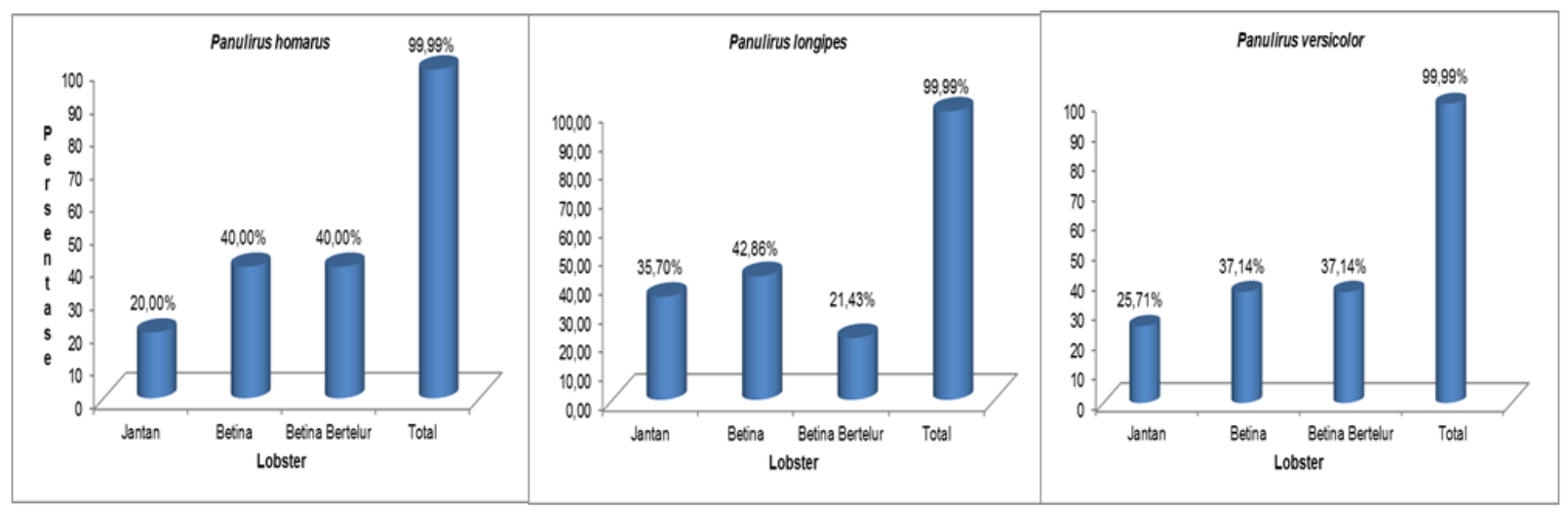

Gambar 5. Persentase Lobster Panulirus homarus, P. longipes dan P. versicolor (Jantan, Betina dan Betina Bertelur) 
Tabel 3 a. Panjang karapas, panjang total dan berat Panulirus homarus dari pantai Pameungpeuk, Selatan Garut

\begin{tabular}{|c|c|c|c|c|}
\hline Jenis kelamin & Panjang karapas \& Panjang Total & Minimum & Rata2 \pm SD & Maximum \\
\hline \multirow[t]{4}{*}{ Jantan } & Panjang karapas/CL (mm) & 20,73 & $22,27 \pm 1,74$ & 89,07 \\
\hline & Panjang Total/TL (mm) & 30,03 & $32,80 \pm 2,65$ & 131,19 \\
\hline & Berat/ W (gram) & 195,50 & $199,10 \pm 2,11$ & 200,90 \\
\hline & Jumlah & 4 & & \\
\hline \multirow[t]{4}{*}{ Betina } & Panjang karapas/CL (mm) & 8,30 & $13,71 \pm 8,30$ & 23,86 \\
\hline & Panjang Total/TL (mm) & 16,87 & $28,83 \pm 10,66$ & 45,98 \\
\hline & Berat/ W (gram) & 11,96 & $243,15 \pm 11,96$ & 400,06 \\
\hline & Jumlah & 8 & & \\
\hline Betina & Panjang karapas/CL (mm) & 9,8 & $76,31 \pm 52,56$ & 132,52 \\
\hline \multirow[t]{3}{*}{ Bertelur } & Panjang Total/TL (mm) & 16,87 & $82,01 \pm 43,40$ & 122,00 \\
\hline & Berat/ W (gram) & 200,00 & $262,07 \pm 89,25$ & 400,46 \\
\hline & Jumlah & 8 & & \\
\hline
\end{tabular}

Tabel 3 b. Panjang karapas, panjang total dan berat Panulirus longipes dari pantai Pameungpeuk, Selatan Garut

\begin{tabular}{llccc}
\hline Jenis kelamin & \multicolumn{1}{c}{ Panjang karapas \& Panjang Total } & Minimum & Rata2 \pm SD & Maximum \\
\hline Jantan & Panjang karapas/CL (mm) & 20,88 & $22,20 \pm 48,53$ & 111,00 \\
& Panjang Total/TL $(\mathrm{mm})$ & 44,30 & $49,22 \pm 3,37$ & 46,71 \\
& Berat/ W (gram) & 198,00 & $199,96 \pm 53,30$ & 201,50 \\
& Jumlah & 5 & & \\
\hline Betina & Panjang karapas/CL (mm) & 18,95 & $25,78 \pm 269,68$ & 38,67 \\
& Panjang Total/TL (mm) & 20,00 & $35,60 \pm 99,35$ & 49,87 \\
& Berat/ W (gram) & 200,42 & $337,13 \pm 29,38$ & 500,20 \\
& Jumlah & 6 & & \\
\hline Betina & Panjang karapas/CL (mm) & 102,09 & $112,84 \pm 156,91$ & 124,76 \\
Bertelur & Panjang Total/TL (mm) & 17,88 & $85,38 \pm 23,28$ & 120,09 \\
& Berat/ W (gram) & 201,40 & $367,53 \pm 57,51$ & 501,02 \\
& Jumlah & 3 & & \\
\hline
\end{tabular}

Tabel 3 c. Panjang karapas, panjang total dan berat Panulirus versicolor dari pantai Pameungpeuk, Selatan Garut

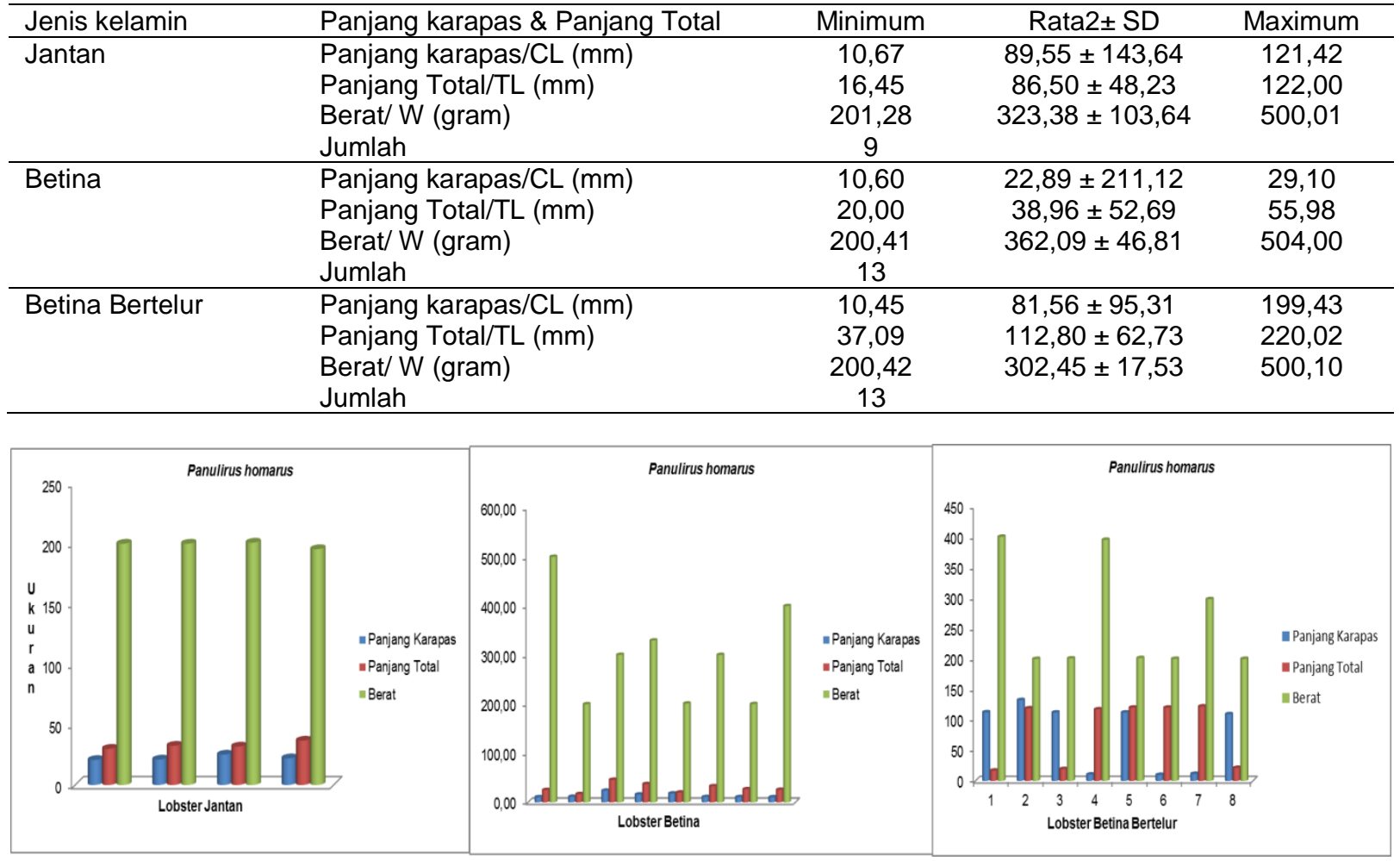

Gambar 6 a. Panjang Karapas, Panjang Total dan Berat Lobster Panulirus homarus (Jantan, Betina dan Betina Bertelur). 


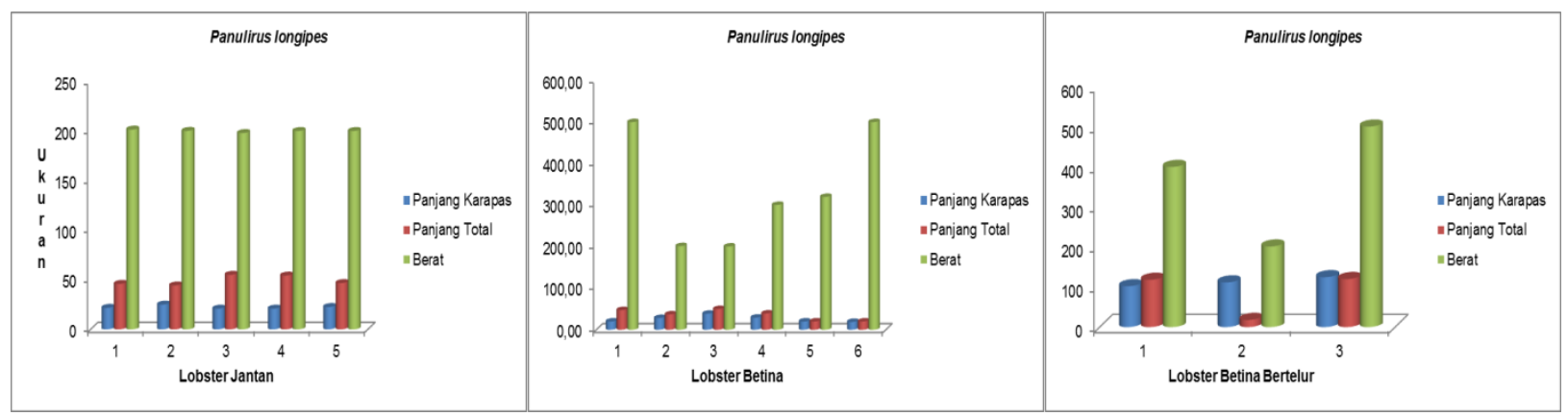

Gambar 6 b. Panjang Karapas, Panjang Total dan Berat Lobster Panulirus longipes (Jantan, Betina dan Betina Bertelur).

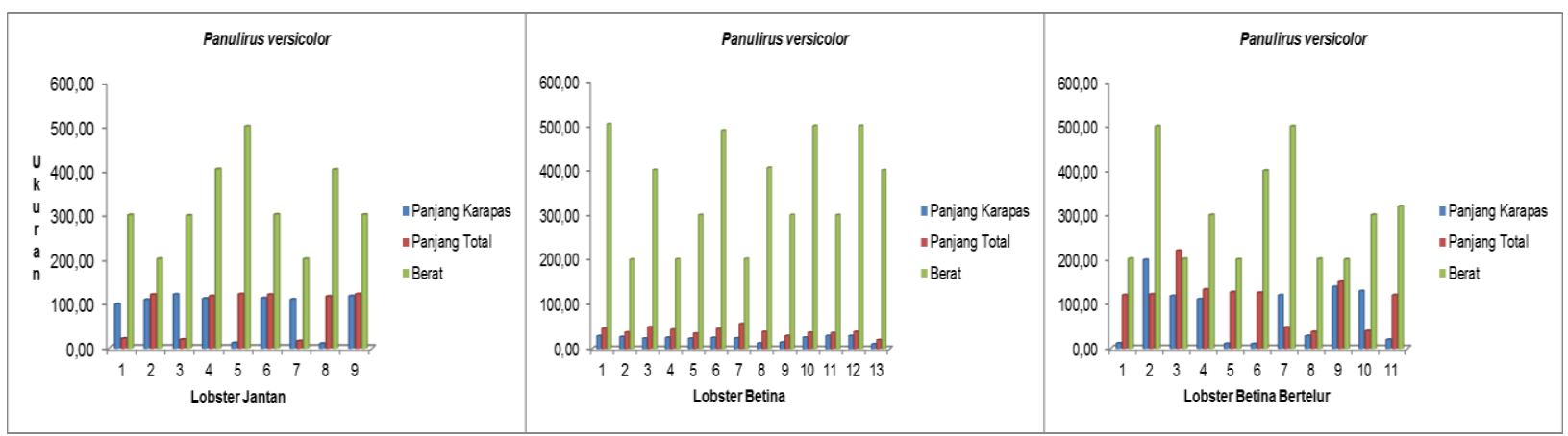

Gambar 6 c. Panjang Karapas, Panjang Total dan Berat Lobster Panulirus versicolor (Jantan, Betina dan Betina Bertelur).

Tabel 4. Rasio kelamin jantan dan betina (Nisbah kelamin) Panulirus homarus, P. longipes dan P. versicolor

\begin{tabular}{|c|c|c|c|c|c|c|c|c|c|c|c|}
\hline Jenis & $\begin{array}{l}\text { Jmh } \\
\text { total } \\
\text { indiv }\end{array}$ & $\begin{array}{c}\text { Jmh } \\
\text { indiv } \\
\delta\end{array}$ & (\%) & $\begin{array}{l}\text { Jmh } \\
\text { total } \\
\text { indiv }\end{array}$ & $\begin{array}{c}\text { Jmh } \\
\text { indiv } \\
\varnothing \\
+\end{array}$ & (\%) & $\begin{array}{l}\text { Jmh } \\
\text { total } \\
\text { indiv }\end{array}$ & $\begin{array}{l}\text { Jmh } \\
\text { indiv } \\
+(\mathrm{ov})\end{array}$ & (\%) & $\begin{array}{c}\text { Rasio } \\
\text { kelamin } \\
\lambda: 0: 9 \\
\text { (ov) }\end{array}$ & $\mathrm{X}^{2}$ \\
\hline$P$. homarus & 20 & 4 & 20,00 & 20 & 8 & 40,00 & 20 & 8 & 40,00 & $1: 2,0: 2,0$ & $4,6^{*}$ \\
\hline P. longipes & 14 & 5 & 35,71 & 14 & 6 & 42,86 & 14 & 3 & 21,43 & $1: 1,2: 1,0$ & $0.6^{*}$ \\
\hline P. versicolor & 35 & 9 & 25,71 & 35 & 13 & 37,14 & 35 & 13 & 37,14 & $1: 1,2: 1,2$ & $0.6^{*}$ \\
\hline
\end{tabular}

${ }^{*}$ Signifikan pada $95 \%$

Demikian pula halnya bila dilihat dari perbandingan ratio kelamin jantan dan betina (Nisbah kelamin) dari dari $P$. homarus, $P$. longipes dan $P$. versicolor (secara terpisah) (Tabel 4), memperlihatkan perbandingan kelamin jantan dari $P$. homarus $(1: 2,0: 2,0) ; P$. longipes $(1: 1,2: 1,0)$ dan $P$. versicolor adalah: $1: 1,2: 1,2$ yang secara statistik menunjukan berbeda nyata $(p<0,05)$. Hal ini mempelihatkan kondisi nisbah kelamin ketiga lobster tersebut berada dalam keadaan seimbang. Nisbah kelamin digunakan untuk keperluan pengetahuan dasar dari biologi reproduksi (Holden \& Raitt, 1974) dan juga untuk melihat populasi suatu organisme dalam mempertahankan populasinya atau disebut juga sebagai indikator kemampuan suatu populasi untuk tetap bertahan melalui rekrutment (Kembaren et al., 2015). Apabila terjadi perbedaan (terjadi tekanan penangkapan yang tidak begitu tinggi), maka menurut Naamin (1971) udang betina dan betina betelur akan selalu lebih banyak dari udang jantan. Seperti halnya dalam penelitian ini, dimana betina dan betina bertelur lebih dominan serta lebih banyak ditemukan. Perbedaan tersebut dapat terjadi karena lingkungan perairan yang berbeda, sehingga pertumbuhan lobster juga berbeda. Menurut Effendi (2002) variasi nisbah kelamin dapat terjadi karena disebabkan oleh tiga faktor, yaitu perbedaan tingkah laku seks, kondisi lingkungan dan lokasi pengangkapan.

\section{Hubungan panjang karapas dan berat tubuh lobster}

Analisa panjang karapas dan berat dari ketiga lobster dapat dilihat pada Gambar 7a, b dan c. dimana perbandingan udang jantan, betina dan betina bertelur dari setiap jenis lobster berbeda beda. Gambar 7 a, $P$. homarus, diperoleh persamaan $\mathrm{W}=181,96 \mathrm{~L}^{0,029} ; \mathrm{W}=$ $485,451 \mathrm{~L}^{-0,2}$ dan $\mathrm{W}=354,371 \mathrm{~L}^{-0,091}$. Sedangkan $P$. longipes (Gambar 7b) diperoleh persamaan W $=186,65 \mathrm{~L}^{0,0222}$; $\mathrm{W}=154,12 \mathrm{~L}^{-1,211}$ dan $\mathrm{W}$ $=0,4654 \mathrm{~L}^{1,3981}$, adapun untuk $P$. versicolor 
(Gambar 7c) diperoleh persamaan $W=719,65 L^{-}$ ,203; $W=431,12 L^{-0,075}$ dan $W=197,51 L^{0,0928}$. Pola pertumbuhan pertumbuhan ketiga jenis lobster (jantan, betina dan betina bertelur) ditunjukkan dengan nilai $\mathrm{t}$ hitung $<\mathrm{t}$ tabel $(\mathrm{b}=3)$ (pada tingkat kepercayaan 95\%) yang artinya pertumbuhan berat udang lebih cepat dari pertumbuhan panjang karapas (Allometrik positif). Penelitian ini sama halnya dengan penelitian lobster pasir oleh Kembaren (2015) di perairan Bali, yang menghasilkan allometrik positif pada pertumbuhan lobster pasir. Namun demikian nilai b atau koefisien pertumbuhan yang diperoleh berbeda dari masing-masing lokasi. Perbedaan tersebut disebabkan oleh faktor biologis seperti perkembangan gonad, kebiasaan makan, fase pertumbuhan dan jenis kelamin (Froose, 2006) dan faktor ekologis seperti: musim, kualitas air, suhu, salinitas, $\mathrm{pH}$, posisi geografis serta pengambilan contoh (Kembaren, 2015). Menurut Wowor (1985), keadaan ini diduga disebabkan oleh perbedaan pertumbuhan dan ukuran yang dapat dicapai lobster jantan, betina dan betina bertelur yang menunjukkan adanya dimorphisma seksual. Hal serupa diperoleh oleh Wowor (1985) pada penelitiannya, dari jenis udang yang sama walaupun tempat berbeda

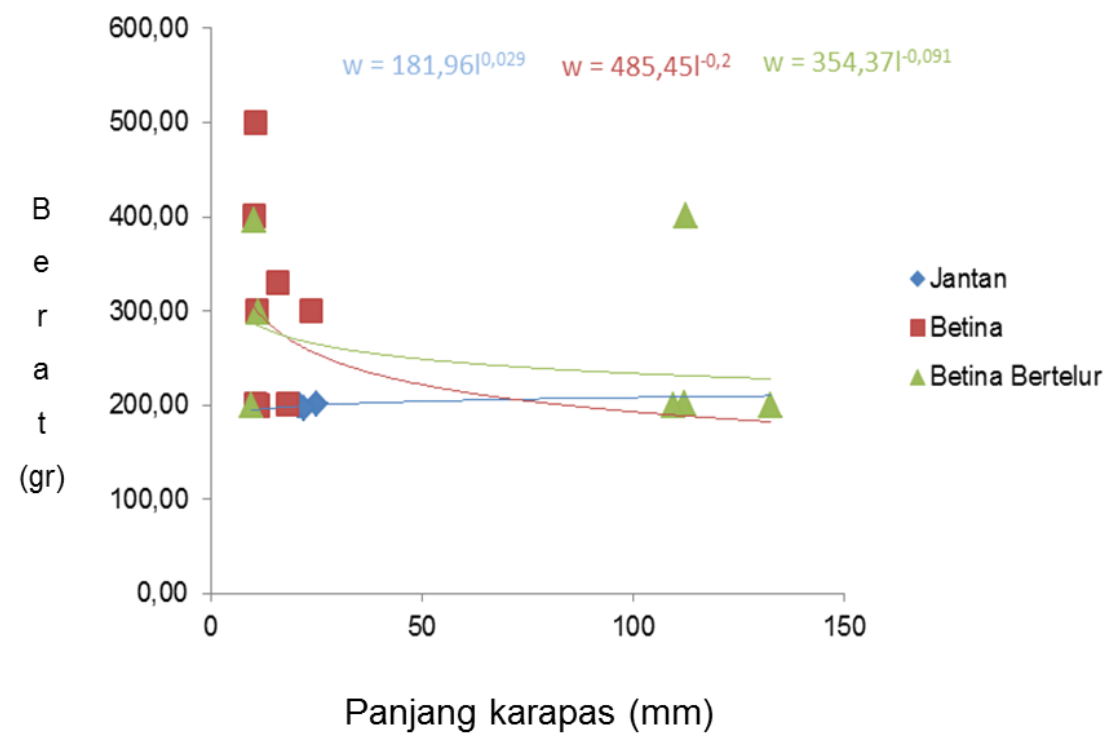

Gambar 7a. Panjang karapas dan berat lobster Panulirus homarus jantan, betina dan betin

a betelur

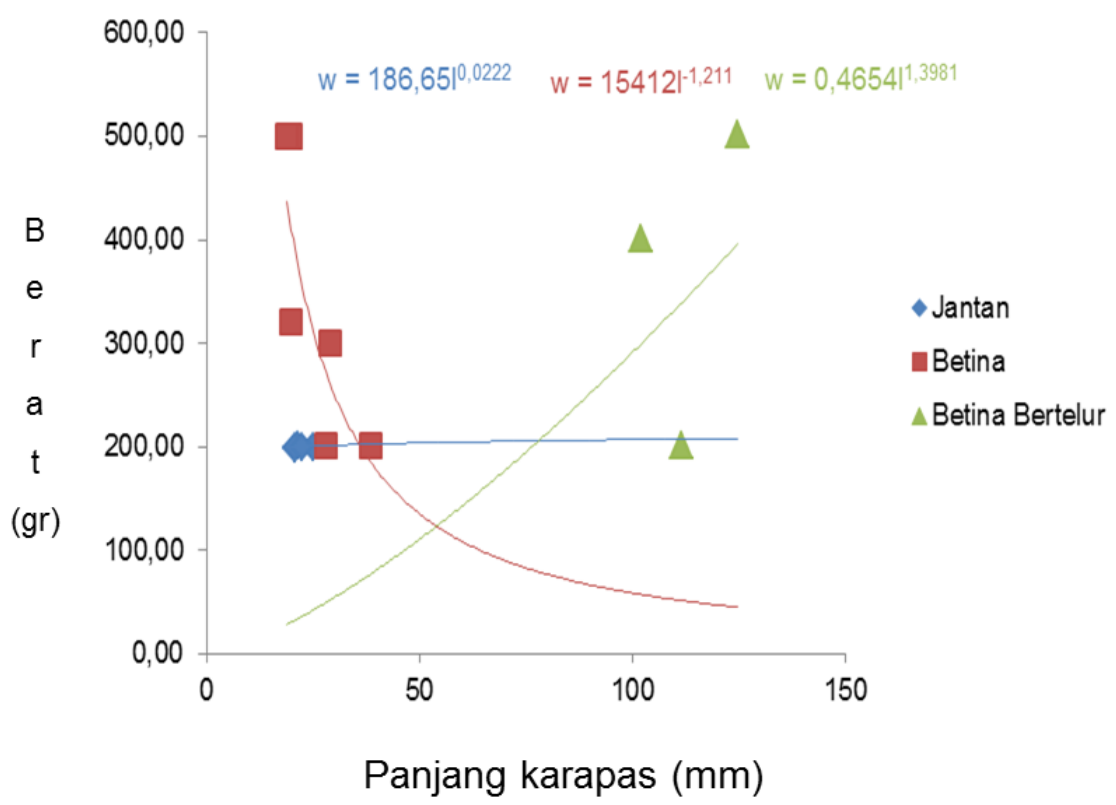

Gambar 7b. Panjang karapas dan berat lobster Panulirus longipes jantan, betina dan betina betelur 


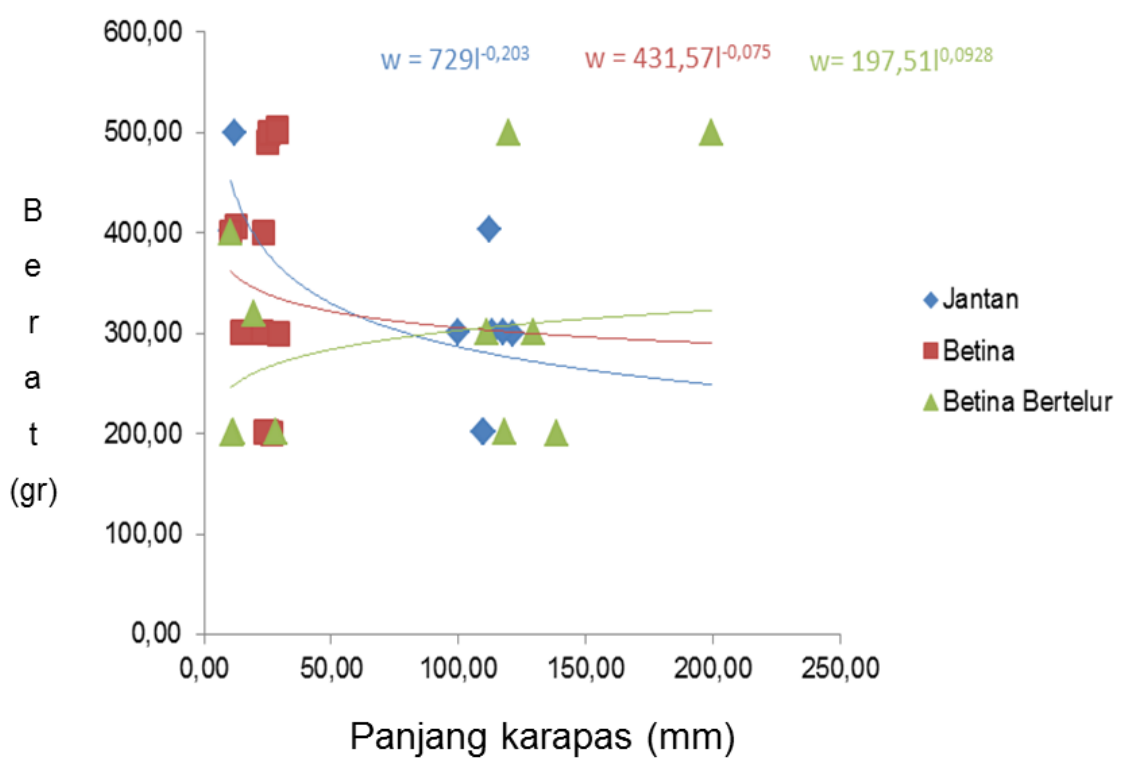

Gambar 7c. Panjang karapas dan berat lobster Panulirus versicolor jantan, betina dan betina betelur

\section{Tingkat kematangan telur}

Lobster betina bertelur memiliki variasi tingkat kematangan telur yang beragam, menurut Fauzi et al., (2013). Kematangan kelamin lobster didasarkan pada perkembangan warna telur pada bagian ventral lobster betina (MacDiarmid \& Marie, 2006). Terdapat beberapa tingkat kematangan telur ditinjau dari warnanya yaitu warna kekuningan, oranye, kecoklatan atau coklat kehitaman. Hasil pengamatan di lapangan didapatkan individu lobster betina bertelur (total dari ketiga jenis) sebanyak 24 ekor (98,57\%) dengan ukuran panjang karapas 29,00 -132,52 $\mathrm{mm}$. Banyaknya individu betina bertelur yang tertangkap rata-rata sudah matang telur yang berwarna coklat kehitaman, kemungkinan saat tertangkap merupakan saat berpijah atau bertelur bagi lobster di daerah Pameungpeuk. Apabila terjadi penangkapan yang overfishing oleh nelayan, maka dapat mengakibatkan terjadinya tekanan terhadap kelestariannya. Hal ini menyebabkan tidak ada kesempatan bagi lobster untuk berkembang biak (Saputra, 2009). Selektifitas penangkapan harus diatur meliputi umur, ukuran dan jenisnya (Fauzi et al., 2013).

\section{Peraturan dan kebijakan pemerintah}

Ketiga jenis lobster ( $P$. homarus, $P$. longipes dan $P$. versicolor, yang ditemukan di Ranca Buaya, Cicalobak, Karang Papak dan Karang Wangi merupakan jenis-jenis yang memang hidup di perairan bergelombang tinggi dan kuat, sepanjang pantai Pameungpeuk, Selatan Garut. Lobster jenis tersebut sangat dicari konsumen, sehingga permintaan lobster di Ranca Buaya, Cicalobak, Karang Papak dan Karang Wangi baik untuk pasar domestik maupun ekspor, terus meningkat. Dampak dari tingginya permintaan dan harga yang semakin meningkat, menyebabkan nelayan terus mencari dan berusaha mengambil dari alam (Fauzi et al., Tim WWF Indonesia, 2015). Hal inilah yang menjadi sangat riskan bagi ketersediaan dan kelestarian lobster, karena tidak diimbangi dengan pembenihan (resctoking), tentu saja akan membahayakan populasi di alam. Menurut Mahdiana \& Laurensia, (2011), ada banyak faktor yang mempengaruhi naik turunnya hasil tangkapan atau produksi udang, diantaranya: faktor alam, cuaca dan musim. Fluktuasi jumlah produksi hasil tangkapan disebabkan adanya kegiatan penangkapan lobster yang masih sangat tergantung pada keadaan alam. Penurunan produksi juga karena meningkatnya intensitas penangkapan yang menyebabkan penyusutan kelimpahan sumberdaya lobster yang tidak sebanding dengan kemampuan pulih dari sumberdaya lobster, sehingga mengakibatkan terancamnya kelestarian sumberdaya lobster itu sendiri. Nelayan menangkap lobster terus menerus tanpa mempehatikan musim pemijahan dari losbter, sehingga mengurangi jumlah populasi lobster tersebut (Mahdiana \& Laurensia, 2011). Selain itu penurunan produksi lobster juga diakibatkan sering terjaringnya anakan lobster $(<$ 100 gram) yang belum layak untuk dijual oleh nelayan di saat puncak musim lobster (bulan November- Januari), sudah diaambil, sehingga sangat berpengaruh pada populasi di alam. Apalagi mereka mengetahui bahwa ukuran tersebut dapat diambil untuk dipelihara/digemukan (fattened) hingga mencapai ukuran layak jual (> 100 gram) (Setyono, 2006).

Beberapa tahun terakhir ini, komoditas penangkapan lobster (udang karang), udang dan kepiting niaga, mulai berkurang bahkan cenderung sedikit merosot, dikarenakan adanya 
peraturan Kementerian Perikanan dan Kelautan yang membatasi dan mengatur penangkapan udang dan kepiting secara khusus, larangan tersebut tertuang dalam Peraturan Menteri Kelautan dan Perikanan RI Nomor 1/Permen$\mathrm{KP} / 2015$ tentang pelarangan penangkapan lobster, kepiting dan rajungan dari betina bertelur dan yang berukuran panjang kurang dari delapan $\mathrm{cm}$. Regulasi tersebut muncul sebagai upaya menjaga kelestarian sumberdaya ikan di laut dan sedang dilakukan pengawasan secara ketat oleh Dinas Kelautan dan Perikanan Jawa Barat. Kenyataan fakta di lapangan selama ini pengawasan penangkapan lobster, udang dan kepiting bertelur di kawasan Selatan Garut belum optimal, walaupun pengawasan untuk ekspor ke luar negri juga dilakukan sangat ketat, saat ini masih ada beberapa nelayan yang menangkap lobster, udang atau kepiting yang sedang bertelur.

Belum sadarnya sebagian masyarakat, pengusaha dan nelayan akan pentingnya penangkapan ramah lingkungan yang bisa menjamin keberlanjutan stock lobster di laut, contohnya, mengambil lobster dengan cara merusak lingkungan yaitu menggunakan bahan peledak dan racun potasium yang tentunya merusak ekosistem dan habitat dari lobster, sehingga berkurang stock komoditas dari lobster tersebut. Eksploitasi yang terus menerus akan berpotennsi mengancam kelestarian sumberdaya lobster laut di Indonesia jika tidak dikelola dengan baik. Dengan adanya pengelolaan yang baik dan bertanggungjawab serta berkelanjutan diharapkan sumberdaya lobster laut di alam dapat tetap terjaga dan bisa terus dimanfaatkan (Tim WWF Indonesia, 2015).

Jenis-jenis lobster yang ditemukan memiliki daur hidup hidup yang sangat kompleks. Lamanya waktu yang dijalani masing-masing lobster berbeda setiap jenisnya. Jenis-jenis yang hidup di perairan tropik umumnya mempunyai daur hidup yang lebih singkat dari jenis-jenis yang hidup di perairan sub-tropik. Lobster yang hidup di daerah tropik umumnya lebih cepat mencapai kedewasaan dibandingkan yang hidup di daerah sub-tropik (Moosa \& Aswandy, 1984; Romimohtarto \& Yuwana, 1999; Mahdiana \& Laurensia, 2011; Pratiwi, 2013). Ukuran panjang lobster betina dewasa rata-rata mencapai panjang karapas $10,50 \mathrm{~mm}$ dan panjang total 220,05 mm, sedangkan lobster jantan mencapai panjang karapas $20,73 \mathrm{~mm}$ dan panjang total $155,00 \mathrm{~mm}$ serta lobster betina bertelur mencapai $9,00 \mathrm{~mm}$ panjang karapas dan panjang total $122,00 \mathrm{~mm}$. Berat rata-rata lobster tersebut mencapai 200 500 gram, dan ini sudah termasuk katagori dari lobster yang boleh ditangkap atau boleh dijual (Tabel 3 dan Gambar 6a,b dan c) (Tim WWF Indonesia, 2015; Peraturan Menteri Kelautan dan Perikanan RI Nomor 1/Permen-KP/2015).
Pantai Pameungpeuk yang memiliki gelombang tinggi dan kuat, merupakan habitat yang disukai oleh ketiga jenis lobster tersebut karena gelombang tinggi dan kuat, dapat memberikan zat hara atau nutrisi yang berlimpah bagi kehidupan biota laut, termasuk lobster karang. Seperti yang dinyatakan oleh Effendi (2002) pertumbuhan organisme merupakan proses biologis yang komplek dengan berbagai faktor yang mempengaruhinya. Ada dua faktor besar yaitu: faktor dalam (intrinsict) dan luar (extrinsict). Faktor dalam meliputi keturunan, sex, umur, parasit dan penyakit. Sedangkan faktor luar yang mempengaruhi pertumbuhan adalah makanan, lingkungan hidup atau habitat dan suhu perairan. Faktor kondisi adalah suatu indikator untuk mengetahui pengaruh lingkungan terhadap kondisi fisik. Secara biologis, lobster merupakan organisme yang berumur panjang dengan pertumbuhan yang lambat (Fauzi et al., 2013). Apabila kondisi lingkungan hidup dari lobster kurang baik (buruk), maka akan menyebabkan berkurangnya pertumbuhan lobster dan apabila lingkungan hidupnya baik serta banyak nutrisi, maka akan berpengaruh terhadap pertumbuhan lobster juga biota laut lainnya. Hal inilah yang juga mempengaruhi kehidupan ketiga lobster di sepanjang pantai Pemeungpeuk Selatan Garut.

\section{Simpulan}

Berdasarkan hasil pengamatan, hanya ditemukan tiga jenis lobster yaitu:, $P$. homarus, $P$ longipes, dan $P$. versicolor dengan jumlah total individu sebanyak 69 ekor, berasal dari Ranca Buaya, Cicalobak, Karang Papak dan Karang Wangi. Jenis lobster tersebut adalah lobster yang dominan ditemukan hidup di perairan bergelombang tinggi dan kuat, sepanjang pantai Pameungpeuk, Selatan Garut.

Dalam penelitian didapatkan ukuran panjang lobster betina dewasa mencapai panjang karapas $10,50 \mathrm{~mm}$ dan panjang total $220,05 \mathrm{~mm}$, sedangkan lobster jantan mencapai panjang karapas $20,73 \mathrm{~mm}$ dan panjang total $155,00 \mathrm{~mm}$ serta lobster betina bertelur mencapai $9,00 \mathrm{~mm}$ panjang karapas dan panjang total $122,00 \mathrm{~mm}$. Berat rata-rata lobster tersebut mencapai 200 500 gram, dan ini sudah termasuk katagori dari lobster yang boleh ditangkap atau boleh dijual.

Hasil analisis gabungan ketiga lobster yaitu: jenis betina $P$. longipes $(14 ; 42,86 \%)$ lebih tinggi persentasenya dibandingkan jenis betina $P$. homarus $(20 ; 40,00 \%)$ dan betina bertelur $P$. versicolor $(35 ; 37,14 \%)$. Jenis jantan $P$. longipes pun $(14 ; 35,70 \%)$ lebih tinggi dari pada $P$. homarus $(20 ; 20,00 \%)$ dan betina bertelur $P$. versicolor $(35 ; 25,71 \%)$. Akan tetapi jenis betina bertelur $P$. longipes $(14 ; 21,43 \%)$ lebih rendah dari jenis betina bertelur $P$. homarus (20; $40,00 \%$ ) dan betina bertelur $P$. versicolor (35; $37,14 \%)$. Ratio lobster betina 120\%: lobster 
betina bertelur $98,57 \%$ dan lobster jantan $81,41 \%$ dari jumlah keseluruhan tangkapan Beda ratio antara ketiga jenis tersebut tidak begitu jauh, dapat dianggap seimbang.

Hasil nisbah kelamin jantan, betina dan betina bertelur dari ketiga jenis lobster secara terpisah, $P$. homarus $(1: 2,0: 2,0) ; P$. longipes $(1: 1,2: 1,0)$ dan $P$. versicolor adalah: 1:1,2:1,2 menunjukan keadaan yang seimbang dan yang dominan tertanggkap cenderung masih berusia muda. Hasil penelitian memperlihatkan pengambilan yang sangat berlebihan, sehingga dapat mengancam kelestarian lobster di alam. Oleh karenanya diperlukan upaya untuk menetapkan ukuran lobster yang boleh ditangkap. Ukuran minimum yang boleh ditangkap adalah di atas ukuran mencapai kematangan kelamin yaitu panjang karapas > 10,52 mm. Penangkapan lobster (udang karang) di Pamengpeuk, Selatan Garut, mulai berkurang dikarenakan adanya peraturan Kementerian Perikanan dan Kelautan yang membatasi dan mengatur penangkapan udang secara khusus, larangan tersebut tertuang dalam Peraturan Menteri Kelautan dan Perikanan RI Nomor 1/Permen-KP/2015 tentang pelarangan penangkapan lobster, kepiting dan rajungan yang bertelur dan berukuran panjang kurang dari delapan $\mathrm{cm}$.

\section{Daftar Referensi}

Bal, D.V. \& K.V. Rao. 1984. Marine fisheries. Tata Mc. Graw-hill publishing company limited. New Delhi: 5-24.

Effendi, I. 2002. Biologi Perikanan. Yayasan Pustaka Nusatama. Yogyakarta: 97 pp.

Fauzi, M., A.P. Prasetyo, I.T. Hargiyanto, F. Satria dan A. A. Utama., 2013. Hubungan panjang berat dan faktor kondisi lobster batu (Panulirus penicillatus) di perairan selatan Gunung Kidul dan Pacitan. Bawal, 5 (2): 97-102.

Febrianti, L., 2000. Pengaruh umpan pikatan kulit hewan (kulit sapi dan kulit kambing) terhadap hasil tangkapan menggunakan krendet dan tingkah laku mencari makan udang karang (lobster) di periaran Baro, kabupaten Gunung Kidul daerah istimewa Yogjakarta. Skripsi. Fakultas Perikanan dan Kelautan, Institut Pertanian Bogor, Bogor.

Hunter, J.R. and S.R. Golberg, 1980. Spawning incidence and batch fecundity in northern anchovy, Engraulis mordax. Fishery Bulletin, 7 (3): 641-652.

\section{Saran}

Sebagai akibat eksploitasi yang terus menerus sering terjadi di alam, maka ada beberapa hal yang perlu diperhatikan sebagai berikut:

1. Tidak menangkap lobster yang berukuran kecil atau sedang bertelur. Jika menemukan lobster dengan kondisi tersebut maka wajib melepaskan kembali ke perairan apabila ada yang tertangkap

2. Lobster yang tertangkap penanganannya harus baik dan benar, meletakkan dalam wadah secara hatihati, agar tidak menyebabkan cacat pada tubuh lobster, karena dapat menyebabkan penurunan harga jual.

3. Wadah penampungan sementara jangan sampai terkena sinar matahari secara langsung, harus ditutup, agar lobster tidak mengalami stress karena penangkapan dan kekurangan oksigen akibat peningkatan suhu di dalam wadah penyimpanan dan dapat menyebabkan kematian.

\section{Ucapan Terima Kasih}

Ucapan terima kasih disampaikan kepada Prof. Drs. Pramudji yang telah memberikan kesempatan untuk ikut dalam penelitian Biota Laut Di Sepanjang Pantai Pameungpeuk, Selatan Garut dan tim yang telah membantu di lapangan.

Holden, M.J. \& D.F.S. Raitt, 1974. Manual of fisheries science.FAO. Rome. Part-2 Methods of resources investigation and their application: 135.

Kembaren, D.D., P. Lestari \& R. Ramdhani. 2015. Parameter biologi lobster pasir ( $P$. homarus) di perairan Tabanan Bali. Bawal, 7 (1): 35-42.

Mac Diarmid, A.B. \& B. S. Marie. 2006. Reproduction, In: B.F. Phillips (Ed). Lobsters: Biology, Management. Aquaculture and Fisheries. Blackwell Publishers: 45-77.

Mahdiana, A. dan S.P. Laurensia, 2011. Status perikanan lobster (Panulirus spp,) di perairan kabupaten Cilacap. Sains Akuatik,13 (2): 52-57.

Moosa, M.K. 1984. Udang karang (Panulirus spp.) dari perairan Indonesia. Lembaga Oseanologi Nasional, LIPI, Jakarta: 40 hal.

Moosa, M.K \& I. Aswandy, 1984. Udang Karang (Panulirus spp). dari perairan Indonesia. Proyek Studi Potensi Sumber Daya Alam Indonesia. Studi Potensi Sumber Daya Hayati Ikan. Lembaga Oseanologi 
Nasional. Lembaga Ilmu Pengtahuan Indonesia, Jakarta. $40 \mathrm{pp}$.

Naamin, N. 1971. Laporan pendahuluan mengenai spawning ground uadang di pantai utara Jawa Tengah. Laporan penelitian Perikanan Laut, 71: 8.

Peraturan Menteri Kelautan dan Perikanan RI Nomor 1/Permen-KP/2015). Tentang penangkapan lobster (Panulirus spp.), kepiting (Scylla spp) dan rajungan (Portunus pelagicus). $5 \mathrm{pp}$.

Pratiwi, R., 2013. Lobster komersial (Panulirus spp). Oseana, 38 (2): 55-68.

Romimohtarto, K. \& S. Juwana, 1999. Biologi laut. Ilmu pengetahuan tentang biota laut. Pusat Penelitian dan Pengembangan Oseanologi-LIPI, Jakarta. 527 pp.

Saputra, S.W. 2009. Status pemanfaatan lobster (Panulirus sp.) di perairan Kebumen. Jurnal Saintek Perikanan, 4(2): 10-15.
Setyono, D.E.D., 2006. Budidaya pembesaran udang karang (Panulirus spp.). Oseana, 31 (4): $39-48$.

Sugandi, D., dan T. Supriatin, 2008. Pengenbangan objek wisata Pantai Santolo, kawasan wisata Pameungpeuk Selatan Garut. Jurusan Pendidikan Geografi, Fakultas Pendidikan IImu Pengetahuan Sosial, Universitas Pendidikan Indonesia, Bandung. 14 pp.

Steel, R.D.G. \& J.H. Torrie, 1993. Prinsip dan prosedur statistika. Suatu pendekatan biometrik. Terjemahan B. Sumantri, Jakarta: PT. Gramedia Pustaka Utama.

Tim Perikanan WWF-Indonesia, 2015. Perikanan lobster laut. Panduan penangkapan dan penanganan. Seri panduan perikanan skala kecil. Better management practices. WWF Indonesia. $22 \mathrm{pp}$.

Wowor, D. 1985. Struktur populasi dan masa reproduksi udang regang. Berita biologi 3 (3): 116-120. 